\title{
A Technical Review of Emerging Technologies for Energy and Water Efficiency and Pollution Reduction in the Textile Industry
}

\author{
Ali Hasanbeigi ${ }^{\text {a }}$, Lynn Price ${ }^{\text {a }}$ \\ ${ }^{a}$ China Energy Group, Energy Analysis and Environmental Impacts Department, Environmental Energy \\ Technologies Division, Lawrence Berkeley National Laboratory, Berkeley CA U.S.A
}

\begin{abstract}
The textile industry uses large amounts of electricity, fuel, and water, with corresponding greenhouse gas emissions (GHGs) and contaminated effluent. Emerging energy-efficiency, greenhouse gas (GHG), and pollution mitigation technologies will be crucial for the textile industry as it responds to population and economic growth that is expected to spur a rapid increase in textile consumption over the coming decades and a corresponding increase in the industry's absolute energy use and GHG and other pollutant emissions. This paper gives an overview of textile industry processes and compiles available information on the energy savings, environmental and other benefits, costs, commercialization status, and references for 18 emerging technologies to reduce the industry's energy use and environmental emissions. Although studies from around the world identify a variety of sector-specific and cross-cutting energy-efficiency technologies that have already been commercialized for the textile industry, information is scarce and/or scattered regarding emerging or advanced energy-efficiency and low-carbon technologies that are not yet commercialized or at the very early stage of adoption. This paper is intended to be a resource on these emerging technologies for engineers, researchers, investors, textile manufacturers, policy makers, and other interested parties.
\end{abstract}

Keywords: Emerging technology; Energy efficiency; Water efficiency; Emissions reduction; Textile industry

\section{Introduction}

\subsection{Background}

The textile industry uses large amounts of electricity, fuel, and water, with corresponding greenhouse gas emissions (GHGs) and contaminated effluent. With regard to energy use, the textile industry's share of fuel and electricity use within the total final energy use of any one country depends on the structure of the textile industry in that country. For instance, electricity is the dominant energy source for yarn spinning whereas fuels are the major energy source for textile wet processing.

In addition to using substantial energy, textile manufacturing uses a large amount of water, particularly for wet processing of materials, and produces a significant volume of contaminated effluent. Conserving water and mitigating water pollution will also be part of the industry's strategy to make its production processes more environmentally friendly, particularly in parts of the world where water is scarce.

In addition to significant $\mathrm{CO}_{2}$ emissions associated with this energy use, combustion of fossil fuels is a key source of air pollutants such as nitrous oxides (NOx), sulfur dioxide (SO2), and particulate matter (PM) in China. Emerging technologies that can help to reduce or improve the efficiency of the use of energy use in the textile industry can result in multiple co-benefits

\footnotetext{
${ }^{1}$ Corresponding author. Address: 1 Cyclotron Rd. MS 90R2002, Berkeley, CA 94720, USA.

Tel.: +1-510 495 2479, email address: AHasanbeigi@lbl.gov
} 
including reduced air pollution and improved human health. If these co-benefits are quantified in monetary values, it will increase the cost-effectiveness of the emerging technologies that often have higher capital cost in the initial stages of adoption.

The world's population increase by around 35\% by 2050 (UN/DESA 2012). This population growth as well as the ongoing economic growth in the developing countries will create significant increases in textile production and consumption, which, in turn, will drive significant increases in the textile industry's absolute energy use, water use, and carbon dioxide $\left(\mathrm{CO}_{2}\right)$ and other environmentally harmful emissions.

Studies such as Hasanbeigi (2010), Carbon Trust (2005), CIPEC (2007), and ECCJ (2007) reviewed the commercially available energy-efficiency technologies. However, because of increased demand of textile products, future reductions in absolute energy use and $\mathrm{CO}_{2}$ emissions will require innovation beyond technologies that are available today.

The studies listed above have identified energy-efficiency technologies for the textile industry that are already commercially available, and other studies (e.g., U.S. DOE/AMO 2012) have identified cross-cutting efficiency technologies that, although not specific to the textile industry, are applicable to this industry. However, information is limited, scattered, and not easily accessible regarding alternative and emerging or advanced energy-efficiency, lowcarbon, water-conservation, and pollution-reduction technologies that have not yet been fully commercialized for the textile industry. The need for a more consolidated source of information which collect all the data and information on emerging technologies for the textile industry from various sources and put it in well-structured and easy to understand format, inspired this research.

The methodology used in this paper has several advantages in comparison to previous studies. First, this study focuses on the emerging technologies and do not review the fully commercialized technologies that are widely adopted like the ones reviewed by Hasanbeigi (2010), Carbon Trust (2005), CIPEC (2007), and ECCJ (2007). Also, the methodology used for this technical review, not only focuses on energy saving benefit from the technologies, but also list other important benefits such as water saving, pollution reduction, productivity gains, etc. In addition, we developed a system to explicitly identify and rank the commercialization status of each technology. Such clear classification is missing in most other studies. This study tries to discuss both advantages and limitations/barriers for each technology where information is available, so the readers will have a more complete picture about the technology reviewed.

This paper first starts by an introduction giving a background about the knowledge gap that inspired this study and advantages of the method used compared to previous studies as well as an introduction to the energy and water use and pollution in the textile industry. Then, the methodology used for this technical review in briefly explained in section 2 . After that the emerging technologies for the textile industry are presented and explained in details in section 3. In section 4, a discussion of the findings are presented followed by summary and conclusions in section 5 .

\subsection{Energy use in the textile industry}

Although the textile industry is not considered an energy-intensive industry, it comprises a 
large number of plants that, together, consume a significant amount of energy. The share of total manufacturing energy consumed by the textile industry in a particular country depends upon the structure of the manufacturing sector in that country. For instance, in 2010, the textile industry accounted for about $4 \%$ of total manufacturing final energy use in China (NBS 2011) but less than $2 \%$ in the U.S. (U.S. DOE 2010). Manufacturing census data from 2010 in the U.S. shows that $53 \%$ of the final energy used in the U.S. textile industry was fuel energy and $47 \%$ was electricity (U.S. DOE 2013). The U.S. textile industry is also ranked as the $6^{\text {th }}$ largest steam consumer amongst 15 major industrial sectors studied in the U.S. The same study showed that around $48 \%$ of the energy input to the textile industry is lost onsite (e.g. in boilers, motor system, distribution, etc.) (ORNL 2012).

A composite textile plant houses spinning, weaving/knitting, and wet processing (preparation, dyeing/printing, finishing) at a single site. Figure 5 shows the breakdown of typical electricity and thermal energy use in a composite textile plant (Sathaye et al. 2005). In Figure 1, spinning consumes the largest share of electricity $(41 \%)$, followed by weaving preparation and weaving (18\%). Wet-processing preparation (de-sizing, bleaching, etc.) and finishing together consume the greatest share of thermal energy (35\%). A significant amount of thermal energy is also lost during steam generation and distribution (35\%). These percentages will vary by plant.

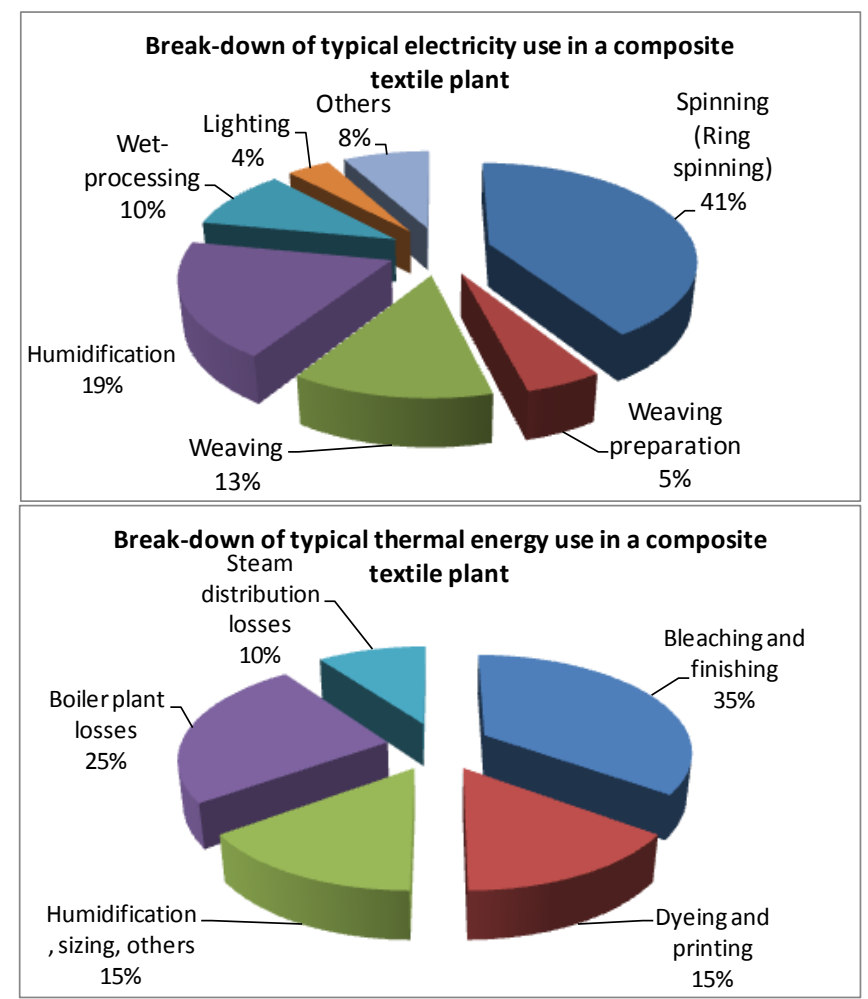

Figure 1. Breakdown of typical electricity and thermal energy use in a composite textile plant (Sathaye et al. 2005)

\subsection{Water use and pollutants in the textile industry}

The textile industry and especially textile wet-processing is one of the largest consumers of water in manufacturing and hence one of the main producers of industrial wastewater. Also, since various chemicals are used in different textile processes like pre-treatment, dyeing, printing, and finishing, the textile wastewater contains many toxic chemicals which if not treated properly before discharging to the environment, can cause serious environmental 
damage. In addition, in many countries, the charges for water supply and effluent discharge are increasing. Hence, for companies to save costs and remain competitive, they need to save water and address issues related to wastewater disposal. EIPPCB (2003) provides a good overview of water consumption and wastewater pollution for different textile wet-processing processes.

\section{Methodology}

The information presented in this paper is collected from publicly available sources and covers the main emerging technologies for an energy-efficient, water-efficient, and lowemission textile industry, but the list of emerging technologies addressed here is not exhaustive. After the compilation of technology list and information for each technology, the paper was reviewed by textile industry experts and their feedback was taken into account in preparing this manuscript.

The paper organizes the information presented about each technology in a standard format: 1) Description of the technology, including background, theory, pros and cons, barriers and challenges, and case studies if available. 2) Energy, environmental, and other benefits of the technology. 3) Commercialization status of each technology as well as resources for further information.

The commercialization status of each technology is as of the writing of this paper and uses the following categories:

- Research stage: The technology has been studied, but no prototype has been developed.

- Development stage: The technology is being studied in the laboratory, and a prototype has been developed.

- Pilot stage: The technology is being tested at an industrial scale at one plant.

- Demonstration stage: The technology is being demonstrated and tested at an industrial scale in more than one plant but has not yet been commercially proven.

- Commercial with very low adoption rate stage: The technology is proven and is being commercialized but has a very small market share.

There are 18 technologies covered in this paper. The paper is solely for informational purposes. Many emerging technologies are proprietary and/or the manufacturers who are developing new technologies are the primary sources of information about those technologies. Therefore, in some cases, we identify the company that is the source of a technology so that readers, if they wish, can seek out more information about the company and product. Emerging technologies continually change, so the information presented in this paper is also subject to change. More detailed information about the technologies discussed in this paper can be found at Hasanbeigi (2013).

\section{Emerging Energy-Efficiency, Water-Efficiency, and Pollution Reduction Technologies}

The subsections below describe emerging technologies that can reduce energy and/or water consumption as well as $\mathrm{CO}_{2}$ and other emissions associated with different subsectors of the textile industry.

Since wet processing of textiles consumes the largest share of energy and water in the industry and is also the primary source of pollution, most of the research has been focused on developing new technologies for this subsector. Thus, a majority of the 18 technologies 
presented in this paper are applicable to textile wet processing.

\subsection{Man-made fiber production}

\subsubsection{Nanoval technology}

The Nanoval process is an alternative technology for production fine man-made fibers by using less energy compared to the conventional spinning technology because it eliminates air heating and air quenching and increases the productivity. This technology is based on a mechanism that produces fine and finest filaments by splitting one melt monofilament into a number (normally around 50, but up to several hundreds) of finer filaments (Nonwovens Industry 2006; Hutten 2007). The monofilaments are picked up directly underneath the spinneret by a gas stream (normally air), which draws them by applying shear stresses to the surface. In contrast to all melt-blown processes, both the melt and air flows are steadily accelerated. As soon as the internal pressure in the monofilament exceeds the external gas pressure, the so-called Nanoval effect causes the filament to burst spontaneously into a multitude of up to several 100 finer filaments per spin hole (NANOVAL GmbH \& Co. KG. 2012).

Nonwoven fabrics can be produced from spliced continuous filaments. In this case, the spinneret nozzles are arranged in rows or as single spin-cones in several parallel rows. The filaments can be deposited on a collector belt running below; gas/air is removed from underneath the belt by a suction fan. Filaments can reach diameters smaller than 1 micrometer $(\mu \mathrm{m})$. Manmade polymers used for nonwovens are mainly polypropylene, polyethylene, polyester, polyamide, and others such as polybutylenterephtalate, polyurethane, and polylactide. Nonwovens made by this technology are used for medical and hygienic webs, filters, wipers, and agricultural webs (NANOVAL GmbH \& Co. KG. 2012).

A pilot plant that could produce a 1-meter (m)-wide web has been built, as well as production plants that can manufacture 3.5 -m-wide web . The weight of the web produced in these plants varies from 5 to 100 grams per square meter (NANOVAL GmbH \& Co. KG. 2012). Table 1 shows the energy, environmental and other benefits as well as commercialization status of the Nanoval technology. Figure 2 shows the schematic of the Nanoval process.

Table 1. Emerging man-made fiber production technology - The Nanoval technology

\begin{tabular}{|c|c|c|c|}
\hline $\begin{array}{l}\text { Technology } \\
\text { Name }\end{array}$ & Energy/Environment/Other Benefits/Costs & $\begin{array}{c}\text { Commercialization } \\
\text { status }\end{array}$ & References \\
\hline $\begin{array}{l}\text { Nanoval } \\
\text { technology }\end{array}$ & $\begin{array}{l}\text { The developer of Nanoval technology claims that it has the following } \\
\text { benefits compared to conventional technologies: } \\
\text { - Use of cold air for spinning, eliminating the need for air } \\
\text { heating } \\
\text { - Lower energy consumption compared to what other } \\
\text { processes require; the difference in energy consumption } \\
\text { compared to conventional technology increases with } \\
\text { increase in filament fineness because the compressed air } \\
\text { used in Nanoval technology consumes less energy than } \\
\text { air heating in conventional technology } \\
\text { - Higher production rate per spinneret } \\
\text { - No need for quenching air for high throughputs and } \\
\text { coarse fibers because spinning uses cold air }\end{array}$ & Pilot & $\begin{array}{l}\text { Nonwovens } \\
\text { Industry } \\
\text { (2006), } \\
\text { NANOVAL } \\
\text { GmbH \& } \\
\text { Co. KG. } \\
(2012)\end{array}$ \\
\hline
\end{tabular}




\subsection{Spinning}

Most new spinning technologies aim to increase productivity, improve or at least retain yarn quality, and ensure increased efficiency in subsequent processing (e.g. weaving, dyeing, and finishing). Vortex spinning has the highest production speed, followed by jet spinning and friction spinning. Table 2 shows the energy, environmental and other benefits as well as commercialization status of these emerging spinning technologies. The description of each technology is presented below.

Table 2. Emerging spinning technologies

\begin{tabular}{|c|c|c|c|}
\hline $\begin{array}{c}\text { Technology } \\
\text { Name }\end{array}$ & Energy/Environment/Other Benefits/Costs & $\begin{array}{c}\text { Commercial } \\
\text { Status }\end{array}$ & References \\
\hline $\begin{array}{l}\text { Vortex } \\
\text { spinning and } \\
\text { jet spinning }\end{array}$ & $\begin{array}{l}\text { Vortex and jet spinning machines have the following benefits compared } \\
\text { to ring and rotor spinning: } \\
\text { - Higher production speed, up to } 450 \mathrm{~m} / \mathrm{min} \text {, which means } \\
\text { approximately 2-3 times greater productivity than rotor } \\
\text { spinning, and } 20-30 \text { times greater productivity than ring } \\
\text { spinning, depending on the yarn count } \\
\text { Lower energy costs than for both ring and open-end rotor } \\
\text { spinning systems, despite the high-pressure air consumption } \\
\text { in vortex spinning } \\
\text { - Less hairiness in yarn, resulting in greater abrasion resistance } \\
\text { and less pilling than fabrics made from ring-spun or open-end } \\
\text { rotor-spun yarns } \\
\text { For Reiter's new J20 machine, } 25 \text { percent less space required } \\
\text { than for ring-spinning equipment producing the same } \\
\text { capacity, resulting in reduced building costs and less climate } \\
\text { control and space conditioning, which in turn saves energy }\end{array}$ & $\begin{array}{l}\text { Commercial } \\
\text { with very low } \\
\text { adoption rate }\end{array}$ & $\begin{array}{l}\begin{array}{l}\text { Erdumlu et al. } \\
(2012), \\
\text { Oxenham } \\
(2003), \\
(2012)\end{array} \quad \text { Rupp } \\
\end{array}$ \\
\hline $\begin{array}{l}\text { Friction } \\
\text { spinning }\end{array}$ & $\begin{array}{l}\text { Friction spinning has the following benefits compared to ring and rotor } \\
\text { spinning: } \\
\text { - Lower yarn-production and preparation costs and energy use } \\
\text { - Yarn tension independent of speed, so high production } \\
\text { speeds, up to } 300 \mathrm{~m} / \mathrm{min} \text {, can be attained } \\
\text { - High twist-insertion rates of up to } 300,000 \text { rounds/min } \\
\text { because of the very low spinning tension } \\
\text { - Greater versatility of fibers used } \\
\text { - Low end-breakage rates therefore greater energy efficiency } \\
\text { - } \quad \text { Er spinning process } \\
\text { - Cleanination of rewinding step, which saves energy } \\
\text { and trash particles. This increase the efficiency in weaving } \\
\text { - } \text { stage. } \\
\text { Production of yarns with better handle }\end{array}$ & $\begin{array}{l}\text { Commercial } \\
\text { with very low } \\
\text { adoption rate }\end{array}$ & $\begin{array}{l}\text { Ishtiaque } \\
(2003), \\
\text { Oxenham } \\
(2002)\end{array}$ \\
\hline
\end{tabular}




\subsubsection{Vortex spinning and jet spinning}

Two companies, Murata Machinery Ltd. and Rieter, make machines that spin yarn using an air vortex that is created in one nozzle block. Murata's device is called a vortex spinning machine and currently dominates the market. Rieter's new device is called an air-jet spinning machine. The vortex spinning machine has a three-roll drafting system and two jet nozzles that create air vortices rotating in opposite directions. The second nozzle creates a false twist on the fiber bundle that emerges from the front roller. Between the front roller and the first nozzle, which creates an air vortex in the opposite direction, the twist is partially removed and some of the edge fibers separate from the fiber bundle; these edge fibers move through the second nozzle either in untwisted form or with a small twist while the core fibers are guided in twisted form through the second nozzle, which untwists them as it twists the edge fibers. The result, when the yarn leaves the second nozzle, is an untwisted core wrapped by twisted edge fibers. The system is reported to be suitable for processing manmade fibers and their blends with cotton. Because the twist is created by airflow in the vortex spinning system, high-speed rotating mechanical parts are not required, so high production rates are possible (Erdumlu et al. 2012).

The raw materials cost is reportedly higher for vortex spinning systems than for ring and open-end rotor spinning systems; this cost increases further when the material contains many short fibers (Erdumlu et al. 2012). Concerns have been expressed that there is excessive fiber loss using the vortex spinning machine. The fiber loss can be about 8 percent, but most of what is lost is short fiber, which does not contribute to yarn quality (Oxenham 2003). Further research is required to analyze airflow in the yarn formation zone and its impacts on yarn structure, in order to improve product quality, e.g., to produce more even yarns in fine counts and softer fabric handle (Erdumlu et al. 2012).

Murata introduced its third-generation vortex spinning machine, the Vortex III 870, at the International Textile Machinery Association (ITMA) exhibition in 2011. This machine is available for up to 96 spinning units with a maximum production speed of 500 meters per minute ( $\mathrm{m} / \mathrm{min})$. At ITMA 2011, Rieter also exhibited J20 air-jet spinning machine, which is double-sided and has 120 spinning units, so it can produce more yarn in a smaller space than other spinning machines. These technologies have higher investment and labor costs than for an open-end rotor spinning system but lower costs than for a ring spinning system (Erdumlu et al. 2012, Oxenham 2002).

\subsubsection{Friction spinning}

Friction spinning forms yarn with the aid of frictional forces in the spinning zone. Frictionspun yarns are characterized by a distinct wrapper surface. Both man-made and natural fibers and their blends can be used as sheath components. The operations involved in friction spinning generally use three units: the fiber-feeding unit, the yarn-forming unit, and the winding-up unit (Ishtiaque 2003).

The fundamental advantage of the friction-spinning system is that one revolution of the twisting element can generate a number of turns per unit length of yarn. Friction spinning is well established for production of medium- and coarse-count yarns. It has potential for high production speeds and twisting rates and is unique in that it can produce a variety of multicomponent yarns, which are preferred for technical textiles. Friction-spun yarns are not normally used to manufacture conventional textiles though they may be used, especially aspile yarns, as weft yarns and for certain knitted goods in which bulk and compressibility are desired. Machines based on the friction spinning principle are Platt Saco Lowell's Master Spinner, DREF-I, DREF-II, DREF-III, DREF-5, DREF-2000, and DREF-3000 (Ishtiaque 
2003).

Some of the main drawbacks and limitations of friction spinning are: Weak yarn due to poor fiber orientation and high twist variation from the surface to the core; significant decrease in yarn tenacity at higher spinning speeds; greater disorientation and buckling with longer and finer fibers; limitation in the fineness of yarns that can be produced because of the large number of fibers required in the yarn cross-section; increase in unevenness and imperfections in yarn as production speed increases; high compressed-air consumption; difficulty holding spinning conditions constant Ishtiaque 2003; Oxenham 2002).

New developments and modifications are essential to deal with the above limitations, improving friction-spun-yarn quality and extending the count range.

\subsection{Weaving}

Compared to other textile subsectors, there are fewer emerging technologies for energy efficiency and emissions reduction in the weaving subsector. This is primarily because most of the new innovation in weaving is focused on production of new products, e.g. technical textiles or increasing the production speed and features of the existing technologies, which sometime could result in energy saving as a result of increased productivity. The subsection below describes one emerging alternative weaving technology: the multi-phase loom.

\subsubsection{Multi-phase loom}

Single-phase weaving machines are close to their performance limits. Research on an alternative approach, multi-phase weft insertion, began in 1955, but the technology did not mature until 1990s. Sulzer demonstrated the M8300 multi-phase loom at ITMA' 1999. The M8300 was designed to be a single-warp machine and earmarked for mass production of standard fabrics without a multi-color mechanism. It has four sheds located in series around the circumference of a weaving central rotor. The warp threads are spread on the shed-holding element with the aid of warp positioners similar to the needle bars on knitting machines. A low-pressure blast of air through a weft channel formed by the shed-holding elements inserts the threads. Additional relay nozzles are placed within the shed-holding elements. The insertion rate is $1,200 \mathrm{~m} / \mathrm{min}$ per shed with an overall rate of $4,800 \mathrm{~m} / \mathrm{min}$ for the machine. The combs positioned on the circumference of the weaving rotor beat up the weft. This loom is reported to have threefold greater productivity, lower specific energy consumption, lower process cost, and to be less noisy than single-phase machines (Matsuo 2008).

Since the introduction of the M8300, the range of yarns, yarn counts, and weaves it can produce has been expanded. Recently, the M8300 has been used exclusively for staple fiber yarns in the yarn count range tex 14.8 - 70 (Ne 8 - 40). Cotton, polyester, viscose, and blends of these yarns can be used as raw materials and have been used to produce fabrics in basic weaves - plain and three- and four-end twill. Filament yarns can now also be woven on the M8300. In the warp, smooth or texturized yarns can be used; in the weft, only texturized yarns can be used (Sulzer Textile 2002).

Table 3 shows the energy, environmental and other benefits as well as commercialization status of this emerging weaving technology. 
Table 3. Emerging weaving technology - Multi-phase loom

\begin{tabular}{|c|c|c|c|}
\hline $\begin{array}{l}\text { Technology } \\
\text { Name }\end{array}$ & Energy/Environment/Other Benefits/Costs & $\begin{array}{c}\text { Commercial } \\
\text { Status }\end{array}$ & References \\
\hline $\begin{array}{l}\text { Multi-phase } \\
\text { loom }\end{array}$ & $\begin{array}{l}\text { The multi-phase loom has the following benefits compared to } \\
\text { single-phase looms: } \\
\text { - Lower energy consumption for the same weaving } \\
\text { output } \\
\text { - Highest production rate of any weaving machine } \\
\text { - Lower labor cost }\end{array}$ & $\begin{array}{l}\text { Commercial with } \\
\text { very low } \\
\text { adoption rate }\end{array}$ & $\begin{array}{l}\text { Matsuo (2008), } \\
\text { Sulzer Textile (2000, } \\
\text { 2002), Seyam 2000) }\end{array}$ \\
\hline
\end{tabular}

\subsection{Textile wet-processing}

Table 4 shows the energy, environmental and other benefits as well as commercialization status of the emerging technologies for the textile wet-processing. The description of each technology is presented below.

Table 4. Emerging wet-processing technologies

\begin{tabular}{|c|c|c|c|}
\hline Technology Name & Energy/Environment/Other Benefits/Costs & $\begin{array}{c}\text { Commercial } \\
\text { Status }\end{array}$ & References \\
\hline $\begin{array}{l}\text { Enzymatic } \\
\text { treatments }\end{array}$ & $\begin{array}{l}\text { Enzymatic scouring has the following benefits compared to alkaline } \\
\text { scouring: } \\
\text { - } 20-50 \text { percent reduction in rinse water consumption } \\
\text { - } \quad 20-40 \text { percent reduction in biochemical oxygen demand } \\
\text { (BOD) and chemical oxygen demand (COD) loads in waste } \\
\text { water } \\
\text { - Reduction in processing time } \\
\text { Enzymatic removal of residual post-bleaching hydrogen peroxide has the } \\
\text { following benefits: } \\
\text { - Energy and water savings because the peroxidases have no } \\
\text { negative influence on the downstream dyeing process, so } \\
\text { liquor does not have to be drained following the enzyme } \\
\text { treatment and prior to dyeing } \\
\text { - Complete biodegradability of peroxidases } \\
\text { Reduction in rinse steps after peroxide bleaching (normally } \\
\text { only one rinse with hot water is necessary after enzyme } \\
\text { treatment) } \\
\text { Avoided wastewater pollution from reducing agents used in } \\
\text { conventional processes }\end{array}$ & $\begin{array}{l}\text { Various } \\
\text { commercializatio } \\
\mathrm{n} \text { stages } \\
\text { depending on the } \\
\text { application }\end{array}$ & $\begin{array}{l}\text { Schönberger } \\
\text { and Schäfer } \\
\text { (2003), Aly et } \\
\text { al. (2004), } \\
\text { Heine and } \\
\text { Höcker (1995) }\end{array}$ \\
\hline $\begin{array}{l}\text { Ultrasonic } \\
\text { treatments }\end{array}$ & $\begin{array}{l}\text { Ultrasonic wet processing has the following benefits: } \\
\text { - Energy savings resulting from lower process temperatures } \\
\text { - } \text { and shorter cycle times } \\
\text { - foduced consumption of dyes and chemicals, which allows } \\
\text { - } 20-30 \% \text { reduction in the amount of effluent } \\
\text { - Improvement in product quality } \\
\text { - Increased productivity because of shorter cycle times }\end{array}$ & Pilot & $\begin{array}{l}\text { Schönberger } \\
\text { and Schäfer } \\
\text { (2003), Vouters } \\
\text { et al. (2004), } \\
\text { EIPPCB (2003), } \\
\text { INTEXUSA } \\
(2010)\end{array}$ \\
\hline $\begin{array}{l}\text { Electron-beam } \\
\text { treatment }\end{array}$ & $\begin{array}{l}\text { E-beam textile surface treatment is reported to have the following } \\
\text { benefits compared to conventional thermal curing: } \\
\text { - Allows for use of solvent-free formulations, which reduces } \\
\text { volatile organic compound emissions during drying } \\
\text { - Can be performed at room temperature, which saves energy } \\
\text { - Reduces processing time and increases productivity }\end{array}$ & Development & $\begin{array}{l}\text { EIPPCB (2003), } \\
\text { Han and Choi } \\
\text { (2010), } \\
\text { Schönberger } \\
\text { and Schäfer } \\
\text { (2003), El- } \\
\text { Naggar et al. } \\
(2003)\end{array}$ \\
\hline $\begin{array}{l}\text { Ozone for } \\
\text { bleaching cotton } \\
\text { fabrics }\end{array}$ & $\begin{array}{l}\text { Use of } \mathrm{O}_{3} \text { gas for cotton bleaching is reported to have the following } \\
\text { benefits compared to conventional hydrogen peroxide bleaching: } \\
\text { - Energy savings because bleaching is achieved at room } \\
\text { temperature without requiring any heating or cooling energy } \\
\text { - Reduced } \mathrm{CO}_{2} \text { emissions by up to } 50 \%\end{array}$ & Development & $\begin{array}{l}\text { Perincek et al. } \\
(2007), \text { Eren } \\
\text { and Ozturk } \\
(2011), \text { Ozone } \\
\text { Bleach }\end{array}$ \\
\hline
\end{tabular}




\begin{tabular}{|c|c|c|c|}
\hline Technology Name & Energy/Environment/Other Benefits/Costs & $\begin{array}{l}\text { Commercial } \\
\text { Status }\end{array}$ & References \\
\hline & $\begin{array}{l}\text { - } \quad \text { Substantial water savings } \\
\text { - } \quad \text { No need for harmful chemicals } \\
\text { Increased productivity because bleaching is done in a very } \\
\text { short time }\end{array}$ & & $\begin{array}{l}\text { Association } \\
(2013 a, b)\end{array}$ \\
\hline $\begin{array}{l}\text { Advanced cotton } \\
\text { fiber pre-treatment } \\
\text { to increase dye } \\
\text { receptivity }\end{array}$ & $\begin{array}{l}\text { The ColorZen cotton fiber pre-treatment technology is reported to have } \\
\text { the following benefits compared to conventional dyeing of non-treated } \\
\text { fibers: } \\
\text { - } \quad 75 \% \text { lower energy consumption because color is applied at } \\
\text { lower dyeing temperatures } \\
\text { - } 90 \% \text { less water consumption because the dye bath is only } \\
\text { filled twice, compared to six or more times with conventional } \\
\text { dyeing. } \\
\text { - Reduced amounts of dyestuff used, and no salt and alkali } \\
\text { required for dye fixation } \\
\text { - Lower cost for treating dye wastewater } \\
\text { - Higher productivity because the dye process is around three } \\
\text { times faster }\end{array}$ & Pilot & $\begin{array}{l}\text { ColorZen } \\
\text { (2012), Textile } \\
\text { World }(2012 a, b)\end{array}$ \\
\hline $\begin{array}{l}\text { Super-critical } \mathrm{CO}_{2} \\
\text { in dyeing }\end{array}$ & $\begin{array}{l}\text { Supercritical } \mathrm{CO}_{2} \text { dyeing has the following benefits compared to } \\
\text { conventional dyeing: } \\
\text { - Almost zero water consumption } \\
\text { - Zero off-gas emissions }\left(\mathrm{CO}_{2} \text { can be recycled) }\right. \\
\text { - No drying step necessary after dyeing, which saves } \\
\text { significant energy } \\
\text { - Leveling and dispersing agents not needed, or, in some cases, } \\
\text { - } \text { used only in very small amounts } \\
\text { Recyclability of dyestuff residues }\end{array}$ & Pilot & $\begin{array}{l}\text { EIPPCB (2003), } \\
\text { Schönberger } \\
\text { and Schäfer } \\
(2003) \text {, Bach et } \\
\text { al. (2002), } \\
\text { Tušek et al. } \\
\text { (2000), DyeCoo } \\
\text { (2012) }\end{array}$ \\
\hline $\begin{array}{l}\text { Electrochemical } \\
\text { dyeing }\end{array}$ & $\begin{array}{l}\text { Electrochemical dyeing is reported to have the following benefits } \\
\text { compared to conventional dyeing: } \\
\text { - Recycling of the mediator system and dyeing liquors, which } \\
\text { significantly reduces chemical and water consumption } \\
\text { - No toxic sulphates and sulphites in effluent, so no adverse } \\
\text { effect on aquatic life } \\
\text { - Lower concentration of chemicals } \\
\text { - Considerably reduced wastewater discharges, which saves } \\
\text { energy at wastewater treatment plants } \\
\text { - Avoidance of odor and other problems caused by } \\
\text { conventional sulfur-containing reducing agents }\end{array}$ & Deve & $\begin{array}{l}\text { Schönberger } \\
\text { and Schäfer } \\
\text { (2003), Das et } \\
\text { al. (2012), } \\
\text { Kulandainathan } \\
\text { et al. (2007b), } \\
\text { Bechtold and } \\
\text { Turcanu (2009), } \\
\text { Roessler and } \\
\text { Crettenand } \\
\text { (2004), } \\
\text { Roessler et al. } \\
\text { (2002) }\end{array}$ \\
\hline $\begin{array}{l}\text { Ink-jet (digital) } \\
\text { printing }\end{array}$ & $\begin{array}{l}\text { Ink-jet textile printing has the following benefits compared to } \\
\text { conventional printing: } \\
\text { - Reduced energy consumption } \\
\text { - Reduced water consumption (washing of printing equipment } \\
\text { is not necessary) } \\
\text { - Indirect printing method (no requirements for printing } \\
\text { - } \text { screens, etc.) } \\
\text { - Ho (or smaller amount of) thickeners required } \\
\text { - Only a small dyestuff palette is needed } \\
\text { - Almost no dyestuff surplus, which reduces load on } \\
\text { - } \quad \text { Fastewater treatment plant } \\
\text { - }\end{array}$ & $\begin{array}{l}\text { Commercial with } \\
\text { very low } \\
\text { adoption rate }\end{array}$ & $\begin{array}{l}\text { Schönberger } \\
\text { and Schäfer } \\
\text { (2003), Matsuo } \\
(2008) \text {, Tyler } \\
(2005)\end{array}$ \\
\hline Plasma technology & $\begin{array}{l}\text { Plasma treatment has the following benefits compared to conventional } \\
\text { treatment techniques: } \\
\text { - Low application temperature, which saves energy } \\
\text { - No (or a small amount of) water and solvents required } \\
\text { - Avoidance of drying steps after plasma finishing, which saves } \\
\text { - } \text { energy } \\
\text { - Shonsiderable savings of dyestuff and finishing auxiliaries } \\
\text { - Considerable improvement in wool prints }\end{array}$ & Pilot & $\begin{array}{l}\text { Kan and Yuen } \\
\text { (2007), Atav } \\
\text { (2013), } \\
\text { Schönberger } \\
\text { and Schäfer } \\
\text { (2003), EIPPCB } \\
\text { (2003) }\end{array}$ \\
\hline Foam technology & Foam finishing has the following benefits compared to conventional & Commercial with & Ramachandran \\
\hline
\end{tabular}




\begin{tabular}{|c|c|c|c|}
\hline Technology Name & Energy/Environment/Other Benefits/Costs & $\begin{array}{l}\text { Commercial } \\
\text { Status }\end{array}$ & References \\
\hline in textile finishing & $\begin{array}{l}\text { finishing techniques: } \\
\text { - Up to } 80 \% \text { reduction in water consumption } \\
\text { - } \quad \text { Up to } 65 \% \text { reduction in energy consumption } \\
\text { - } \quad \text { Reduced wastewater discharge } \\
\text { - Increased production speed (stenter speed can be increased } \\
\text { - } \text { for drying, or stenter and pre-drying can be eliminated) } \\
\text { - } \quad \text { Improved finished-fabric physical properties } \\
\text { - } \quad \text { Payback period as short as six months to two years }\end{array}$ & $\begin{array}{l}\text { very low } \\
\text { adoption rate }\end{array}$ & $\begin{array}{l}\text { et al. (2008), } \\
\text { Elbadawi and } \\
\text { Pearson (2003), } \\
\text { MEOEA (1999) }\end{array}$ \\
\hline Microwave energy & $\begin{array}{l}\text { Microwave heating in textile wet processing has the following benefits } \\
\text { compared to conventional heating techniques: } \\
\text { - Lower energy use } \\
\text { - No direct air pollution (indirect air pollution from electricity } \\
\text { use is still less than that resulting from conventional heating ) } \\
\text { Localized heating, which reduces energy waste in the heating } \\
\text { process } \\
\text { - Faster heating, which increases productivity and reduces } \\
\text { energy use } \\
\text { - More uniform heating }\end{array}$ & Development & $\begin{array}{l}\text { Büyükakınc1 } \\
(2012), \text { Bhat et } \\
\text { al. (2009), } \\
\text { Katovic et al. } \\
\text { (2010 and } \\
2005)\end{array}$ \\
\hline $\begin{array}{l}\text { Alternative textile } \\
\text { auxiliaries }\end{array}$ & $\begin{array}{l}\text { One or more of the following benefits can be achieved by alternative } \\
\text { textile auxiliaries compared to conventional auxiliaries: } \\
\text { - Reduced energy and water consumption } \\
\text { - Reduced environmental pollution } \\
\text { - Higher productivity } \\
\text { - } \quad \text { Reduced load on wastewater treatment facilities }\end{array}$ & $\begin{array}{l}\text { Various stages of } \\
\text { commercializatio } \\
\mathrm{n} \text { depending on } \\
\text { the type of } \\
\text { auxiliary }\end{array}$ & $\begin{array}{l}\text { Hauser (2006), } \\
\text { Schönberger } \\
\text { and Schäfer } \\
(2003)\end{array}$ \\
\hline
\end{tabular}

\subsubsection{Enzymatic treatments in textile wet processing}

Enzymes are proteins that act as biocatalysts, activating and accelerating chemical reactions that would otherwise normally require more energy. The excellent substrate selectivity of enzymes allows more gentle process conditions compared to conventional forms of wet processing. Enzymes are present in bacteria, yeasts, and fungi (EIPPCB 2003).

Enzymes are used in textile finishing processes and are being studied for use specifically with natural fibers. Some state-of-the-art commercial enzymes include amylase for de-sizing starch and cellulose for bio-finishing. Enzymatic mixtures for cotton scouring, cotton bleaching, wool scouring, anti-felting, silk degumming, and flax softening are still in development (Nieminen et al. 2007).

Advantages of enzymatic processes compared to conventional techniques include lower processing temperatures and lower water consumption (because of reduced rinsing steps and cooling water use). Another benefit of enzymes is their biodegradability. Enzymes can also be used in catalytic amounts and recycled for reuse as biocatalysts (Schönberger and Schäfer 2003). Two of the major applications of enzymes in textile wet processing are explained in more detail below.

\section{Enzymatic scouring:}

De-sizing, scouring with strong alkali, and bleaching are typical pre-treatment steps in cotton finishing mills. The scouring and bleaching steps are often combined. Scouring improves the wettability of cotton fibers by removing hydrophobic impurities, such as pectines and waxes. Enzymatic scouring, using enzymes in combination with surfactants (wetting agents and emulsifiers) and complexing agents, can replace the alkaline scouring process. Because enzyme-scoured textiles have better bleachability than textiles scoured by other methods, the quantities of bleaching chemicals and auxiliaries can be reduced for enzymatically scoured products (Schönberger and Schäfer 2003; Aly et al. 2004). 
The enzymatic scouring process can be applied to cellulosic fibers and their blends, to woven and knitted goods, and in continuous or discontinuous processes. Enzymatic pre-treatment can also be combined with enzymatic de-sizing. Existing machines (jets, overflows, winches, pad batchers, pad steamers, and pad rollers) can be used with enzymatic scouring (Schönberger and Schäfer 2003).

\section{Enzymatic removal of residual hydrogen peroxide after bleaching:}

To achieve reproducible bleaching results, a residual hydrogen peroxide content of 10-15 percent of the initial quantity needs to remain in yarns or fabrics after bleaching but must then be completely removed before the textile is dyed to prevent any change of shade when using dyestuffs that are sensitive to oxidation. Common peroxide-removal techniques use reducing agents and several rinsing steps. The main disadvantages of these conventional peroxideremoval techniques are high energy and water consumption and the use of sulphur-containing reducing agents (Schönberger and Schäfer 2003).

Special enzymes (peroxidases) catalyze the reduction of hydrogen peroxide to oxygen and water without causing side reactions with the substrate or dyestuffs. Enzymatic peroxide removal is possible in discontinuous, semi-continuous, and continuous processes and is applicable both in new and existing installations (Schönberger and Schäfer 2003). Heine and Höcker (1995) discuss enzymatic bleaching for wool and cotton.

\subsubsection{Ultrasonic treatments}

The frequency of ultrasonic waves is above 16 kilohertz $(\mathrm{kHz})$, which is outside the audible range for human beings. To propagate, these waves require a medium with elastic properties. Ultrasonic waves cause the formation and collapse of bubbles (known as cavitation), which is generally considered to be responsible for most of the physical and chemical effects of ultrasound that are observed in solid/liquid or liquid/liquid systems (Vouters et al. 2004, Guglani 2008).

Ultrasonic waves can be created by mechanical transducers, piezoelectric transducers, or magnetic transducers. Ultrasound equipment consists of two main components: a generator and a converter or cleaning bath. The generator converts 50- to 60-Hertz (Hz) alternating current to high-frequency electrical energy, which is then fed to the transducer where it is transformed into mechanical vibration. The transducer system vibrates longitudinally, transmitting waves into a liquid medium. As these waves propagate, cavitation occurs (Guglani 2008).

During the past 20 years, experimental studies were performed on dyeing and washing of natural and man-made fibers assisted by ultrasound. In dyeing processes, the object is to transport or diffuse dyes or chemicals into a fiber (Vouters et al. 2004). Acoustic irradiation of the liquor results in a higher and more uniform concentration of dyestuff on the fiber surface, making it available for ready diffusion into the fiber interior (Ramachandran et al. 2008; EIPPCB 2003). Cavitation induced by ultrasound can accelerate these processes and produce the same results as existing techniques but at a lower temperature and lower dye and chemical concentrations (Vouters et al. 2004; Atav 2013).

Attempts have been made to analyze the effect of ultrasonic waves on dyeing using reactive and acid dyes as well as dye dispersants with almost all types of fibers. The ultrasonic method has been effectively utilized in various fabric preparation processes including de-sizing, 
scouring, bleaching, mercerization, as well as auxiliary processes such as washing (Ramachandran et al. 2008).

Vouters et al. (2004) and Ramachandran et al. (2008) review several studies on the use of ultrasonic waves in dyeing of polyamide, cotton, and nylon fabrics. Several studies have shown that ultrasonic treatment can speed up the washing process by two to three times or more for cotton, polyester, or wool fabrics (Vouters et al. 2004).

The lower cost of electronic components today compared to in the past makes the industrial application of ultrasound in dyeing and washing processes a feasible option. This technique can be implemented using existing machinery.

The current restrictions on use of the ultrasound process in the textile industry are: 1) the kinetics of reaction because fixation times are limited by the nature of dyes and chemicals, 2) thermal limitations because, although an increase of temperature accelerates reactions, too high a temperature can damage textiles, and 3) mechanical limitations because textiles can be damaged if the pressure of the rollers used for hydro-extraction is too high (Vouters et al. 2004). Figure 3 shows the schematic of ultrasonic textile washing machine.

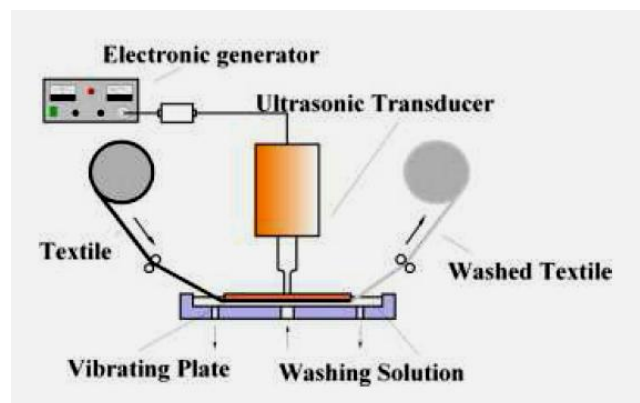

Figure 3. Schematic of ultrasonic textile washing machine (FLAiNOX 2011)

\subsubsection{Electron-beam treatment}

An electron beam (E-beam) or ray is generated by high voltage in an E-beam accelerator, which produces high-energy electrons (generally 300 kiloelectron-volts [keV] to 12 megaelectron-volts $[\mathrm{MeV}])$. These electrons can be used to modify polymer materials through direct electron-to-electron interactions, which can create active sites such as radicals. Active sites can be formed on the polymer backbone by several methods, including plasma treatment, ultraviolet radiation, decomposition of chemical initiators, and high-energy radiation. Currently, the most common radiation types in industrial use are gamma and E-beam. Industrial E-beam accelerators with energies in the 150-300 keV range are used where low penetration is needed, such as for curing of surface coatings. E-beam machines have a high dose rate and therefore short processing times. E-beams have limited penetration compared with gamma radiation, and they use energy more efficiently because the energy can all be absorbed by the irradiated sample (Atav 2013).

E-beam irradiation is being increasingly utilized to modify the surfaces of polymer materials, such as fibers, textiles, and films. Electron beams cause free-radical-initiated polymerization reactions that can then be used for coating, lamination and for graft co-polymerization on textiles pre-coated with monomers or polymers. The advantage of E-beam irradiation over thermal curing is that it allows use of solvent-free formulations, which reduces volatile organic compound emissions during drying. The technique is already established in other 
sectors, so its implementation in the textile industry is foreseeable in the near future (EIPPCB 2003).

The textile chemical manufacturer Ciba has developed a series of dyes that contain polymerizable vinyl groups and are suitable for printing. E-beam irradiation can be used for fixation after printing with a paste containing a dye monomer and a specially selected cationic monomer. In lab tests, the target of $100 \%$ dye utilization was approached, and minimal washing off was required (Lewis 1999).

\subsubsection{Use of ozone for bleaching cotton fabrics}

Conventional bleaching of cotton consumes large amounts of energy, water, and chemicals (hydrogen peroxide, etc.) and pollutes the water with chemical components and suspended solid particles. Ecological concerns have prompted a search for solutions to reduce the pollution resulting from the bleaching process. Utilizing ozone $\left(\mathrm{O}_{3}\right)$ to prepare cotton is one way to decrease these environmental impacts. $\mathrm{O}_{3}$ 's oxidation potential is 2.07 electron-volts $(\mathrm{eV})$, which is higher than that of the widely used bleaching agent, hydrogen peroxide (1.77 eV). $\mathrm{O}_{3}$ is available in molecular form at an acidic $\mathrm{pH}$ (Eren and Ozturk 2011).

The use of $\mathrm{O}_{3}$ for bleaching cotton is still under development. Various studies show that the whiteness of cotton fabric bleached with $\mathrm{O}_{3}$ is comparable to that of conventionally bleached fabric but with greater decreases in degrees of polymerization. The $\mathrm{O}_{3}$ process is environmentally preferable to peroxide bleaching because, when $\mathrm{O}_{3}$ is used, there is no need for other harmful chemicals, much less water is required, and bleaching is achieved in a very short time at room temperature without the need for heating or cooling energy (Perincek et al. 2007; Prabaharan et al. 2000).

The equipment used for $\mathrm{O}_{3}$ bleaching has three components: the ozone generator, the applicator, and the ozone destroyer (Rane and Jadhav n. d.). The input for the generator is oxygen from a pressurized cylinder. The generator supplies the required concentration of $\mathrm{O}_{3^{-}}$ oxygen mixture to the applicator, a glass cylindrical tube with a diffuser at the bottom (Rane and Jadhav, n. d.). $\mathrm{O}_{3}$ is produced by subjecting the $20 \%$ of oxygen present in air to pressure swing adsorption and raising its concentration to $90 \%$; then, plasma discharge is used to generate $\mathrm{O}_{3}$ (Ozone Bleach Association 2013a).

In a study by Eren and Ozturk (2011), $\mathrm{O}_{3}$ was used in to prepare fibers for de-sized and scoured $100 \%$-cotton fabrics. The study found that hydrogen peroxide-bleached, 60-min ozonated, and 90-min ozonated samples all had a similar degree of whiteness. Loss in strength after prolonged ozonation was negligible (Eren and Ozturk 2011).

\subsubsection{Advanced cotton fiber pre-treatment technology to increase dye receptivity}

Altering the molecular structure of cotton fiber can increase its dye receptivity so that smaller amounts of dye and no salt and alkali are required. The ColorZen cationic process is based on this pre-treatment concept (ColorZen 2012).

Because the only auxiliary dye chemical used in the ColorZen process is a small amount of wetting agent, overall chemical use is reduced by 95 percent compared to traditional dye processes. If the ColorZen dyebath is recycled for reuse in a subsequent dyeing process, the wetting agent in the bath also can be reused. The initial cost of the process is slightly higher than that of conventional cotton pre-treatment processes, but no capital investment is required for new equipment. In the longer term, savings from reduced energy, water, dye, and chemical 
usage can compensate for the extra initial cost. The process can be used on any $100 \%$-cotton fabric (knitted or woven). One possible exception is denim because of its indigo-dyed warp. There are concerns about variations in dye fixation with this process, which the manufacturer is working to improve (Textile World 2012a). ColorZen opened its first processing facility in China (Textile World 2012b).

\subsubsection{Use of supercritical carbon dioxide in dyeing}

All materials above critical temperatures and pressures are supercritical fluids (Tušek et al. 2000; Atav 2013). $\mathrm{CO}_{2}$ is frequently used as a solvent because of its non-toxic, non-corrosive, and non-hazardous nature as well as the fact that it is produced commercially and can be transported easily. It is relatively easy to achieve critical temperature and pressure for $\mathrm{CO}_{2}$ compared to other gases (Ramachandran et al. 2008).

Using supercritical $\mathrm{CO}_{2}$ as a dye medium is a promising emerging process. The key property of supercritical $\mathrm{CO}_{2}$, that makes dyeing possible is its ability to dissolve hydrophobic substances, including dye dispersants. The supercritical fluid performs two functions in the dyeing process: it heats the substrate and transports the dyes. The process can be controlled by temperature and pressure (Tušek et al. 2000).

The dissolved dyestuff that diffuses into the boundary layers of the supercritical fluid is absorbed and diffuses into the fibers. The state of the dyestuff in a super critical solution can be described as gaseous (Ramachandran et al. 2008). The supercritical $\mathrm{CO}_{2}$ dyeing process uses almost no water, and drying is not required because, at the end of the process, $\mathrm{CO}$ is released in the gaseous state. Up to $90 \%$ of the $\mathrm{CO}_{2}$ can be recycled easily after precipitation of the extracted matter in a separator (Bach et al. 2002).

$\mathrm{CO}_{2}$ dyeing of polyester (the most widely used textile fiber) and polypropylene fiber has already been developed on an industrial scale; however, the application of this technique on wool, polyacrylate, and cotton is still problematic because of the polar nature of the dyestuffs used to color these fibers. Dyeing of polyester in supercritical $\mathrm{CO}_{2}$ should be performed at a pressure above 180 bar and a temperature above $70^{\circ} \mathrm{C}$ (Tušek et al. 2000; EIPPCB 2003).

A disadvantage of this technology is the substantial investment cost for the equipment. This is a significant drawback because polyester textiles are normally low-price products (EIPPCB 2003).

The Dutch company DyeCoo Textile Systems produced the first industrial dyeing machines that use super critical $\mathrm{CO}_{2}$. The polyester textile producer Tong Siang Co. Ltd in Thailand is the first textile mill to implement a commercial-scale supercritical fluid $\mathrm{CO}_{2}$ machine. Currently, the process is used only for dyeing of scoured polyester fabric in batches of 100$150 \mathrm{~kg}$ although DyeCoo and its partners are developing reactive dyes for cellulosic fibers (Textile machinery 2010).

\subsubsection{Electrochemical dyeing}

Vat dyes (including indigo) and sulfur dyes account for a large part of the dyestuff market for cellulosic fibers. In addition to their well-known advantages, vat and sulfur dyes have a complicated application procedure, involving reduction and oxidization steps (Schönberger and Schäfer 2003).

Conventional reducing agents used for the reduction of dyestuffs result in non-regenerable 
oxidized byproducts that remain in the dyebath. Used dyebaths cannot be recycled because the reducing power of these chemicals cannot be regained. Disposal of these dyebaths and associated wastewater causes a variety of environmental problems, e.g., introducing into the environment sulphite and sulphate from the use of dithionite, sulphides from sulphur dyes, and causing a high COD because of the presence of organic reducing agents (Das et al. 2012).

An attractive alternative technique is to reduce and oxidize dyes using electrochemical methods. In direct electrolysis, the dye is reduced at the surface of the cathode (EIPPCB 2003). In practice, the dyestuff is partially reduced using a conventional reducing agent; then, a complete dye reduction is achieved using the electrochemical process. This improves the stability of the reduced dye (Das et al. 2012).

In indirect electrochemical dyeing, the dye is not directly reduced at the electrode surface. Rather, a reducing agent (regenerable $\mathrm{Fe}_{2}{ }^{+} / \mathrm{Fe}_{3}{ }^{+}$) that reduces the dye in the conventional manner is added. This agent is oxidized after dye reduction and subsequently reduced at the cathode surface so that it becomes available again for reducing dyes. This cycle repeats continuously during the dyeing operation. In electrochemistry, an agent that undergoes both reduction and oxidation cycles (a reversible redox system) is called a mediator (Das et al. 2012).

Electrochemically reduced vat dyes have been tested on a laboratory scale in dyeing experiments; the results of different reduction conditions are discussed by Kulandainathan et al. (2007b), Bechtold and Turcanu (2009), Roessler et al. (2004), and Roessler et al. (2002). Austria-based Getzner Textil signed a cooperation agreement in 2001 with the Technology Team Electrochemistry Textile (TET), headed by DyStar Textilfarben, Germany. Under the agreement, Getzner was the first company to pilot DyStar's patented electrochemical dyeing process. Getzner used the technology to vat-dye yarn on a package-dyeing unit (Textile World 2002). Issues that must be addressed in scaling-up of the indirect electrochemical reduction process are discussed in Kulandainathan et al. (2007a).

\subsubsection{Ink-jet printing (Digital printing)}

Ink-jet or digital printing of textiles emerged in the 1990s for prototyping and printing small batches of fabric for niche market products. This technology has developed dramatically since then (Tyler 2005). In simplified terms, ink jet printing of textiles is a contactless technology that works similarly to an office printer. It enables quick response and a great deal of flexibility especially in patterning. Color type and position on the textile are recorded digitally and supplied to the printing system. The transformation of the sample on the substrate takes place via innumerable ink drops pressed out of printing nozzles. Several drops of one color generate each "dot" of the dots per inch (dpi) that make up the digital image. A raster program puts these drops one upon another or side by side using an organizing principle based on base shade, tinctorial power, and pattern. The two types of ink-jet printing for textiles are continuous flow and drop on demand, shown in Figures 15 and 16 (Schönberger and Schäfer 2003; Matsuo 2008).

Most fabrics need pre-treatment before digital printing; the extent of pre-treatment depends on the inks to be used. Pre-treatment chemicals inhibit dye from migrating once it has landed on the substrate and can also be used to control $\mathrm{pH}$. Digitally printed inks have low viscosity to allow flow through the print head; for comparison, screen-printing pastes have a viscosity of about 5,000 mega-Pascals (mPas) whereas ink jet fluids have a much lower viscosity of 3 to $15 \mathrm{mPas}$. This low viscosity creates problems when the ink reaches the textile substrate 
because fluid moves away from the target by wicking. Therefore, the textile substrate has to be prepared by adding a thickener that provides enhanced absorbency to prevent wicking. In some cases, the thickener can cause the textile to develop a hard handle. If this adversely affects its end use, a scouring process is required after printing to remove the thickener (as well as unfixed dye). In other cases, there may be no adverse handle effects, eliminating the need for scouring (Tyler 2005).

Every printed fabric (except those used for transitory purposes such as photo shoots) needs post-treatment to complete the printing process. Steaming opens up the fabric's fibers, so the dyes can be fixed. Generally, steaming for a short time $\left(8-10\right.$ minutes at $\left.102{ }^{\circ} \mathrm{C}\right)$ is considered to produce prints with weak colors; strong, vibrant colors require steaming for at least 17 minutes. Often, washing is required because the uptake of acid and reactive dye is never $100 \%$; this creates particular requirements for processing small batches. For commercial reasons, post-treatments are not done unless the end use requires them. So, for example, printed fabrics intended for photo shoots are not even fixed. Pre-treated fabrics are not scoured unless necessary to remove impurities (Tyler 2005).

A representative advanced printing machine exhibited at ITMA 2007 can dye 80 square meters per hour $\left(\mathrm{m}^{2} / \mathrm{h}\right)$ of 320 -cm-wide fabric using 16 colors at $600 \mathrm{dpi}$. The printing process can be used for reactive, acid, dispersant, and pigment dyeing. In March 2008, a machine with an operation speed of $400 \mathrm{~m}^{2} / \mathrm{h}$ using eight colors at 600 dpi was presented by a Japanese company. Figure 4 and Figure 5 show the drop-on-demand concept and continuous ink-jet concept.

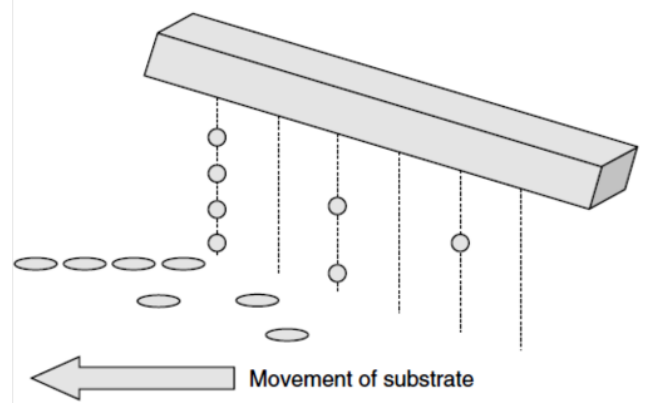

Figure 4. Drop-on-demand concept (a drop of ink is produced in reponse to a signal to fire the nozzle) (Tyler 2005)

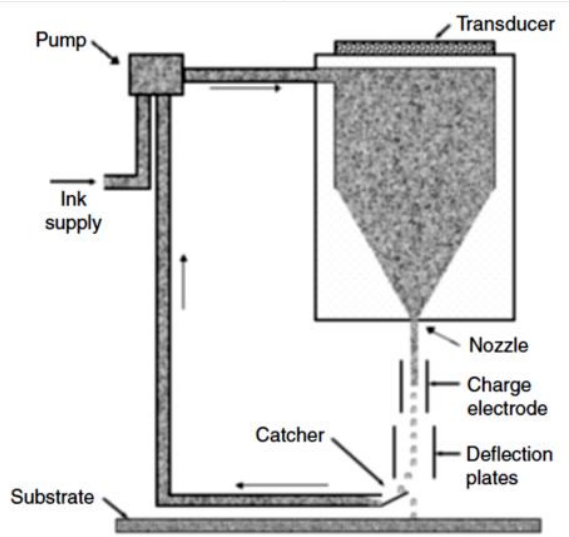

Figure 5. Continuous ink-jet concept (drops of ink are produced continuously and either fall on the substrate or are recycled) (Tyler 2005) 


\subsubsection{Plasma technology in textile wet processing}

Plasma can be characterized as a mixture of partially ionized gases; that is, plasma contains gases that are decomposed as a result of high induced electrical energy. Atoms, radicals, ions, and electrons can be found in plasma. Low-temperature plasmas normally used for surface treatment contain electrons with high kinetic energy compared to the gas temperature. The electrons in the plasma can cleave covalent chemical bonds. Therefore, physical and chemical modification of the surfaces of various substrates is possible with plasma technology. Two types of plasma are generally used: corona and low-pressure (EIPPCB 2003).

Plasma treatment can be performed on natural as well as on man-made fibers. Plasma treatment for apparel and industrial textiles includes the following possible applications: pretreatment (de-greasing of wool, de-sizing), changes in wettability (hydrophilic, hydrophobic properties), pre-treatment for dyeing and printing (increasing dyestuff affinity, improving leveling properties, increasing bath exhaustion), and shrinkage and anti-felt finishing for wool (most studied and very promising; plasma treatment causes less degradation of the wool fiber than other processes and avoids the presence of absorbable organic halides in the wastewater). Additional applications of plasma treatment in the textile industry include: sterilization (antibacterial finish), improvement of textile stability in response to aggressive gases and fluids, and improvement of fiber matrix adhesion (for use in composites) (Schönberger and Schäfer 2003).

The structure of fibers and the structure and construction of yarn and fabrics play major roles in determining the efficiency of plasma processing. Plasma processing is affected by the presence of impurities in raw fibers and of additives in yarn and fabrics (Nasadil and Benesovsky 2008). Nasadil and Benesovsky (2008) investigated the possibilities for plasma pre-treatment in different forms of textile wet processing. Developments in plasma treatment for wool have been reviewed by Kan and Yuen (2007). Some of the effects of plasma treatment on dyeability of proteinous fibers are summarized in Atav (2013).

A plasma-treated wool surface has favorable dye uptake, finish, and adhesion properties. Because plasma-treated woolen materials have better dye pick-up, more color value can be achieved with these wool fabrics than with untreated fabrics, for the same strength of dyestuff. The plasma treatment enhances the surface tension of the wool, which in turn increases the fabric's adhesion property during coating. The plasma treatment also significantly improves the wool's shrink-proofing. Because it is a physical process, plasma treatment does not involve any industrial effluent, so it eliminates the pollution associated with chemical treatments (Kan and Yuen 2007).

Although industrial-scale continuous plasma treatment is in the investigation stage, atmospheric pressure plasma treatment equipment can be inserted "inside" existing textileprocessing machines so that the plasma treatment can be carried out in line immediately before the traditional process, as an alternative to continuous plasma treatment (Kan and Yuen 2007). Of the two types of plasma, corona technology has the advantages of easy construction and handling. One fundamental reason why low-pressure plasma technology is not realized on a commercial scale is that a vacuum is needed, so textiles that will receive this treatment have to be dried carefully. The high volume of fabrics that is treated, humidity of the textiles (especially in case of natural fibers), and presence of residual auxiliaries lead to high operating costs of the plasma treatment; thus, the humidity and residual auxiliaries should be reduced to minimum before the plasma treatment. (Schönberger and Schäfer 2003). Figure 6 shows an aapparatus for atmospheric low-temperature plasma treatment. 
(1) glass jar, (2) brass electrode, (3) dielectric layer (polyamide), (4) gas inlet, (5) gas outlet,(6) specimen for treatment

Figure 6. Apparatus for atmospheric low-temperature plasma treatment (Kan and Yuen 2007)

\subsubsection{Foam technology for textile finishing}

Wet processing of textile materials consumes a large amount of energy and accounts for a major share of the energy used in the textile industry in many countries. Most of this energy is consumed in heating and evaporation of water from fibers. Also, a large amount of water is consumed in textile wet-processing. Foam finishing is an alternative method in which the liquor is diluted using air instead of the water that is normally used to apply chemicals to textile materials. Because most of the water that is normally used is replaced by air in foam finishing, energy requirements in the drying processes are reduced along with water consumption and wastewater disposal (Ramachandran et al. 2008). Foam technology also offers a solution to a basic problem encountered with other low-add-on topical and expression systems: the difficulty of distributing a relatively small quantity of liquor uniformly over a large surface of fabric (Elbadawi and Pearson 2003).

Foam is a colloidal system comprised of a mass of gas bubbles dispersed in a liquid continuum. Foam can be generated mechanically by air blowing or excess agitation, chemically by introduction of foaming agents, or by a combination of these methods. The relative proportions of air and liquid phases in the foam are designated by the blow ratio. Foam stability, density, and diameter are important parameters that need constant attention. Systems commonly used in foam applications are: horizontal padders, kiss roller coating, knife-over-roller coating, knife on air, and slot applicators. After foam is applied to fabrics, it can be destroyed by conventional padding, vacuum application, or a combination of both (Ramachandran et al. 2008).

Foam can be used in fabric preparation, dyeing and printing, durable press finishing, softening, soil-release finishing, mercerizing, and various types of finishes (water- and oil-repellant, fire retardant, anti-static, etc.). The foam can be applied on one or both sides of the fabrics (Ramachandran et al. 2008). Foam finishing systems can be retrofitted on most existing equipment (Gaston Systems 2012).

\subsubsection{Microwave energy in textile wet processing}

Microwaves are electromagnetic waves with frequencies ranging from 1,000 megahertz $(\mathrm{MHz})$ 
to10,00,000 MHz (Guglani 2008). Microwave energy has found a number of applications in industrial processes in various sectors where it is used as an alternative to conventional heating techniques because it provides fast, uniform, and effective heating by penetrating the particles in matter and enabling their simultaneous heating. Advantages of microwave energy include: shorter application times, quicker heating and drying, ability to easily change process time to heat different volumes of material, and energy conservation (Büyükakınc1 2012).

In the textile industry, microwave energy has been tested in heating, drying, condensation, dyeing, pressing, finishing, and modifying the surface of materials. The first attempt to use microwaves in the textile finishing process was during the 1970s when cellulose fabrics were treated with durable press finishing agents and cured in a microwave oven (Katovic et al. 2005).

An example of the use of microwaves in textile production is microwave dyeing, which takes into account the dielectric and thermal properties of the process. The dielectric property refers to the intrinsic electrical properties that affect the dyeing by dipolar rotation of the dye; these electrical properties influence the microwave field on the dipoles. An aqueous dye solution has two polar components. The high-frequency microwave field oscillating at $2,450 \mathrm{MHz}$ influences the vibration energy in the water and dye molecules. The heating mechanism is ionic conduction, which is a type of resistance heating. The acceleration of the ions through the dye solution causes dye molecules to collide with the molecules of the fiber. A mordant affects the penetration of the dye, including the depth of penetration into the fabric (Guglani 2008).

Safety measures must be developed prior to using microwave energy on a large scale because excessive exposure to microwave radiation is hazardous (Katović 2011). Büyükakıncı (2012), Atav (2013), and Katovic (2010) review various application of microwave energy in textile wet processing.

\subsubsection{Alternative textile auxiliaries}

A significant trend in textile manufacturing is toward environmentally friendly textile products that use less energy and water and fewer toxic chemicals. This trend is being driven in part by government restrictions on chemical use. New textile chemicals need to provide the desired performance with a minimum of pollution. Recent developments to reduce the environmental impact of textile auxiliaries are reviewed below (Hauser 2006).

The bio-scouring process utilizes several enzymes to catalyze hydrolysis of warp sizes and impurities in cotton. Specialty surfactants have been developed that claim to allow combining of de-sizing and scouring without the use of amylase; these surfactants can disperse and remove starch sizing in alkaline solutions. Incorporating a biodegradable stabilizer into a hydrogen peroxide bleach bath reduces the load on wastewater treatment facilities.

Alkyl phenol ethoxylates that are used in textile processes are excellent surfactants but biodegrade to materials that are toxic to aquatic life, so many textile chemicals have been reformulated to remove alkyl phenol products.

Use of peroxide bleach activators can reduce the time and temperature associated with hydrogen peroxide bleaching. Two such activators are tetraacetylethylenediamine and nonanoyloxy-benzene sulfonate, which have been adopted on a limited basis in the textile industry (Hauser 2006) . 
Another technology under development is the use of cationizing agents on cotton prior to dyeing. Cationic cotton utilizes dye better and has higher color values than cotton not pretreated in this manner. In addition, the strong dye-fiber interactions resulting from cationizing allow dyeing with no added electrolytes and minimal rinsing and after-washing (Hauser 2006).

Use of polyasparginic acid as a substitute for conventional dispersing and complexing agents is under study. This product is biodegradable and does not have potential to remobilize toxic heavy metals. Polycarbonic acids can be used as an alternative to N-methylol-based crosslinking agents, which are responsible for formaldehyde emissions (EIPPCB 2003; (Schönberger and Schäfer 2003).

Recent softener advancements include a silicone oil that is self-emulsifiable and $96 \%$ active. This product reduces shipping and inventory costs and can be made into a useful emulsion in the mix room. A $100 \%$ active cationic non-silicone softener is available that can be added directly to dyeing machines without prior dilution or emulsification (Hauser 2006).

\subsection{Sensor and control technologies}

Table 5 shows the energy, environmental and other benefits as well as commercialization status of the emerging sensor and control technologies. The description of each technology is presented below.

Table 5. Emerging sensor and control technologies

\begin{tabular}{|c|c|c|c|}
\hline $\begin{array}{l}\text { Technology } \\
\text { Name }\end{array}$ & Energy/Environment/Other Benefits/Costs & $\begin{array}{l}\text { Commercial } \\
\text { Status }\end{array}$ & References \\
\hline $\begin{array}{l}\text { Fuzzy logic } \\
\text { and other } \\
\text { expert } \\
\text { systems }\end{array}$ & $\begin{array}{l}\text { Fuzzy logic and other expert systems in textile processes } \\
\text { have the following benefits compared to conventional } \\
\text { control techniques: } \\
\text { - Improved process control, which can increase } \\
\text { productivity and enhance the quality of the final } \\
\text { product } \\
\text { - } \quad \text { Potential savings in energy and chemicals as a } \\
\text { - } \text { result of the improved process control } \\
\text { - } \text { Ophorter processing time } \\
\text { - More reliable processing } \\
\text { - Fewer additions and shading operations } \\
\text { - Reduced effluent load }\end{array}$ & $\begin{array}{l}\text { Various stages of } \\
\text { commercialization } \\
\text { depending on the } \\
\text { application }\end{array}$ & $\begin{array}{l}\text { EIPPCB (2003), Shim } \\
\text { (2009), Shamey and } \\
\text { Hussain (2003), DyStar } \\
(2010)\end{array}$ \\
\hline $\begin{array}{l}\text { Real-time on- } \\
\text { line } \\
\text { monitoring } \\
\text { systems }\end{array}$ & $\begin{array}{l}\text { On-line monitoring systems have the following benefits } \\
\text { compared to conventional textile-production control } \\
\text { techniques: } \\
\text { - Reduced energy use } \\
\text { - Reduced water consumption } \\
\text { - Reduced use of chemicals/avoidance of excess } \\
\text { chemical use } \\
\text { - Reduced re-processing and enhanced right-first- } \\
\text { - } \quad \text { Reduced load on wastewater treatment facilities }\end{array}$ & Pilot & $\begin{array}{l}\text { EIPPCB (2003), U.S. } \\
\text { EPA (1996) }\end{array}$ \\
\hline
\end{tabular}

\subsubsection{Fuzzy logic and other expert systems in the textile industry}

Process reliability can be improved significantly with the use of expert systems, which are essentially computer programs that either recommend or make decisions based on knowledge collected from experts in the field (rule-based systems) or databases of previous formulations (case-based systems) (Shim 2009).

Textile wet processing involves the interaction of a large number of variables whose exact relation to product properties has yet to be established conclusively. This is because of the 
high degree of variability in raw materials, the complexity of multi-stage processing, and a lack of precise control of process parameters, among other reasons (Shim 2009).

Expert systems can integrate the perspectives of individual disciplines (e.g., pre-treatment, dyeing, finishing) into a framework for decision making for textile production. Expert systems have been employed in many fields within the textile industry. Some of these applications are reviewed below. A more comprehensive review of expert systems in the textile industry can be found in Shim (2009).

In dyeing and finishing, expert systems are used for bleaching cotton fabrics, determining dyeing recipes, optimizing dyeing processes, executing textile finishing recipes and monitoring performance, selecting fluorescent whiteners, matching color and optimizing labto-bulk reproducibility, and managing the dyeing control system (Shim 2009; Shamey and Hussain 2003).

Fuzzy logic is based on self-learning software systems, which auto-enlarges their knowledge using algorithms (EIPPCB 2003). A fuzzy logic system is useful when a situation has too many variables to account for all of them with complete precision. The fuzzy logic general inference process proceeds in three (or four) steps as shown in Figure 20 (Shim 2009).

Major areas of fuzzy logic application in the textile industry include classification, grading, diagnosis, planning, and control. The main strength of fuzzy logic is that it can address uncertainty and imprecision in decision-making processes, for example cotton color classification. A fuzzy inference system that uses fuzzy logic to classify cotton colors has been developed; the preliminary results show it is effective in reducing machine-classer disagreements about color grading, and that it shows good consistency over multiple years of cotton color data (Shamey and Hussain 2003). Fuzzy logic also can be used to control the sizing process and the condensation reaction among cross-linking agents (EIPPCB 2003; Shim 2009).

Heriot-Watt University developed a diagnostic fuzzy logic system for the dyeing of cotton material (Shim 2009). Another example of the use of fuzzy logic is for speed control of looms. A computer program has been developed to simulate the speed control of weaving machines using fuzzy logic. The program is based on an assessment of the weaver's load, the running behavior of the weaving machine, the speed range, and the shutdown frequency (Shamey and Hussain 2003).

The main limitation in the implementation of these expert systems in the textile industry is often the lack of a reliable database (EIPPCB 2003).

\subsubsection{Real-time on-line monitoring systems}

Process control by on-line monitoring enhances operation reliability and helps ensure rightfirst-time production by enabling the operator to evaluate important process parameters in real time. Many systems include predictive models that can quickly adjust operating variables to achieve the desired result (U.S. EPA 1996).

Examples of ongoing research in on-line process control area are (EIPPCB 2003):

Dyeing: chemical oxygen demand (COD) concentration (in relation to dyestuff concentration) is measured on line during washing and rinsing operations in discontinuous dyeing processes. When the dyestuff concentration in the rinse bath is negligible, the rinsing process is 
automatically stopped. This technique saves considerable water and energy compared to systems that are not monitored in real time.

Dyeing and bleaching: A special amperometric sensor enables on-line control of the concentration of reducing or oxidizing agents in fabrics. For example, the completeness of hydrogen peroxide removal after bleaching or the concentration of reducing agents in vat dyeing can be monitored so that excess chemical use can be avoided.

Dyeing with vat dyes: By monitoring the redox potential, it is possible to detect exactly the point at which the reducing agent is completely rinsed off. When this point is reached, the rinsing process can be stopped and the oxidant added to the bath, which can save water and reduce chemical use and water pollutant emissions

\section{Discussion}

This paper compiles information for 18 emerging technologies to reduce the textile industry's energy use, water use, and environmental emissions. Most of the technologies reviewed result in substantial energy saving, water saving, time saving, material saving, and/or reduction in wastewater pollution compared to the conventional technologies. Table 6 illustrates some of the main benefits achieved by emerging wet-processing technologies.

Table 6. Comparison of some of the benefits achieved by emerging wet-processing technologies

\begin{tabular}{|c|c|c|c|c|c|}
\hline Technology Name & $\begin{array}{r}\text { Energy } \\
\text { Saving } \\
\end{array}$ & $\begin{array}{r}\text { Water } \\
\text { Saving }\end{array}$ & $\begin{array}{c}\text { Material } \\
\text { Saving }\end{array}$ & Time saving & $\begin{array}{c}\begin{array}{c}\text { Reduced wastewater } \\
\text { pollution }\end{array} \\
\end{array}$ \\
\hline Enzymatic treatments & $\bar{X}$ & $\bar{X}$ & $\bar{X}$ & $\bar{X}$ & $\bar{X}$ \\
\hline Ultrasonic treatments & $\mathrm{X}$ & $\mathrm{X}$ & $\mathrm{X}$ & $\mathrm{X}$ & $\mathrm{X}$ \\
\hline $\begin{array}{l}\text { Electron-beam } \\
\text { treatment }\end{array}$ & $\mathrm{X}$ & $\mathrm{X}$ & $\mathrm{X}$ & $\mathrm{X}$ & \\
\hline $\begin{array}{l}\text { Ozone for bleaching } \\
\text { cotton fabrics }\end{array}$ & $\mathrm{X}$ & $\mathrm{X}$ & $\mathrm{X}$ & & $\mathrm{X}$ \\
\hline $\begin{array}{l}\text { Advanced cotton fiber } \\
\text { pre-treatment to } \\
\text { increase dye receptivity }\end{array}$ & $\mathrm{X}$ & $\mathrm{X}$ & $\mathrm{X}$ & $\mathrm{X}$ & $\mathrm{X}$ \\
\hline $\begin{array}{l}\text { Super-critical } \mathrm{CO}_{2} \text { in } \\
\text { dyeing }\end{array}$ & $\mathrm{X}$ & $\mathrm{X}$ & $\mathrm{X}$ & & $\mathrm{X}$ \\
\hline Electrochemical dyeing & $\mathrm{X}$ & $\mathrm{X}$ & $\mathrm{X}$ & & $\mathrm{X}$ \\
\hline Ink-jet (digital) printing & $\mathrm{X}$ & $\mathrm{X}$ & $\mathrm{X}$ & & $\mathrm{X}$ \\
\hline Plasma technology & $\mathrm{X}$ & $\mathrm{X}$ & $\mathrm{X}$ & $\mathrm{X}$ & $\mathrm{X}$ \\
\hline $\begin{array}{l}\text { Foam technology in } \\
\text { textile finishing }\end{array}$ & $\mathrm{X}$ & $\mathrm{X}$ & $\mathrm{X}$ & $\mathrm{X}$ & $\mathrm{X}$ \\
\hline Microwave energy & $\mathrm{X}$ & & & $\mathrm{X}$ & \\
\hline $\begin{array}{l}\text { Alternative textile } \\
\text { auxiliaries }\end{array}$ & $\mathrm{X}$ & $\mathrm{X}$ & $\mathrm{X}$ & & $\mathrm{X}$ \\
\hline
\end{tabular}

This study consolidates the available information on emerging technologies for the textile industry and puts it in a well-structure format to assist engineers, researchers, investors, textile companies, policy makers, and other interested parties. Although adoption of specific technologies in any given region around the world is driven by local conditions - economic viability, raw materials availability, the type of energy type used and its cost, and the regulatory regime - this paper is intended to be of use to a wide audience.

Many of the technologies reviewed have not been commercialized yet. Therefore, further 
research is needed to improve and optimized these technologies in order to make them commercial. In addition, for some technologies, there was not much information available except from the technology developer. Conducting independent studies and validation on the fundamentals, development, and operation of these emerging technologies can be helpful to private and public sectors as well as academia.

Shifting away from conventional processes and products will require a number of developments including: education of producers and consumers; new standards; aggressive research and development to address the issues and barriers confronting emerging technologies; government support and funding for development and deployment of emerging technologies; rules to address the intellectual property issues related to dissemination of new technologies; and financial incentives (e.g., through carbon trading mechanisms) to make emerging cleaner technologies, which might have a higher initial costs, competitive with the conventional processes and products.

\section{Summary and Conclusions}

This paper describes 18 emerging energy- and water-efficiency and pollution reduction technologies for the textile industry. The information presented for each technology was collected from various sources, including manufacturers. It is likely that no single technology will be the best or only solution but instead that a portfolio of technologies should be developed and deployed to address the increasing energy and water use and emissions of the textile industry.

Most of the technologies reviewed result in substantial energy saving, water saving, time saving, material saving, and/or reduction in wastewater pollution compared to the conventional technologies. However, most of the reviewed emerging technologies have not been commercialized; hence, further effort is needed to prepare these technologies for full commercialization and market deployment.

\section{Acknowledgments}

This work was supported by the China Sustainable Energy Program of the Energy Foundation through the U.S. Department of Energy under Contract No. DE-AC02-05CH11231. We are thankful to William Oxenham of college of textile of North Carolina State University and Perry L. Grady of American Association of Textile Chemists and Colorists for their valuable comments and feedback on the earlier version of the report. We also would like to thank Nan Wishner and Rousida Lin for their assistance in editing and formatting this report.

\section{References}

Aly, A. S., A. B. Moustafa, A. Hebeish. 2004. Bio-technological treatment of cellulosic textiles. Journal of Cleaner Production, 12(7), 697-705.

Atav, R. 2013. The Use of New Technologies in Dyeing of Proteinous Fibers. Available at: $\mathrm{http} / / / \mathrm{www}$.intechopen.com/books/eco-friendly-textile-dyeing-and-finishing/the-use-of-newtechnologies-in-dyeing-of-proteinous-fibers

Bach, E., E. Cleve, E. Schollmeyer. 2002. Past, present and future of supercritical fluid dyeing technology-an overview. Review of Progress in Coloration and Related Topics, 32(1), 88-102.

Bhat, N. V., M. J. Kale, A. V. Gore. 2009. Microwave radiations for heat-setting of polyester 
fibers. Journal of Engineered Fibers and Fabrics, 4, 1-6.

Büyükakınc1, B. Y. 2012. Usage of Microwave Energy in Turkish Textile Production Sector. Energy Procedia, 14, 424-431.

Canadian Industry Program for Energy Conservation (CIPEC). Benchmarking and best practices in Canadian wet-processing. 2007. Available at: http://oee.nrcan.gc.ca/industrial/technicalinfo/benchmarking/ctwp/index.cfm

Carbon Trust. Low cost heat recovery at W \& J Knox Ltd, Ayrshire. Good Practice. 2005. Available at: www.carbontrust.co.uk

ColorZen. 2012. ColorZen: How it works/the benefits. Available at: http://www.colorzen.com/

Das, D., K N Chatterjee, S. Arora. 2012. Electrchemical Dyeing of Cellulosics: A Novel Method. The Indian Textile Journal, January, 2012.

DyeCoo. 2012. DyeCoo $\mathrm{CO}_{2}$ dyeing technology. Available at: http://www.dyecoo.com/

Elbadawi, A. M., J. S. Pearson. 2003. Foam Technology in Textile Finishing. Textile Progress, 33(4), $1-31$.

El-Naggar, A. M., M. H. Zohdy, S. S. Mohammed, E. A. Alam. 2003. Water resistance and surface morphology of synthetic fabrics covered by polysiloxane/acrylate followed by electron beam irradiation. Nuclear Instruments and Methods in Physics Research Section B: Beam Interactions with Materials and Atoms, 201(4), 595-603.

Energy Conservation Center, Japan (ECCJ). 2007. Overview of Energy Saving Technologies in Textile Industry. Available at: http://www.aseanenergy.org/download/projects/promeec/20072008/industry/eccj/ECCJ_SW03\%20Overview\%20of\%20energy\%20saving\%20technology_TH.pdf

Erdumlu, N. , B. Ozipek, W. Oxenham. 2012. Vortex spinning technology. Textile Progress, 44:3-4, 141-174.

Eren, H. A., D. Ozturk. 2011. The evaluation of ozonation as an environmentally friendly alternative for cotton preparation. Textile Research Journal, 81(5), 512-519.

European Integrated Pollution Prevention and Control Bureau (EIPPCB). 2003. Reference Document on Best Available Techniques for the Textiles Industry. Available at http://eippcb.jrc.es/reference/BREF/IS_Adopted_03_2012.pdf http://eippcb.jrc.ec.europa.eu/reference/ FLAiNOX. 2011. Ecomondo 2011. Available at: http://www.flainox.com/blog/2011/11/ecomondo-ecoindustrial-revolution/

Gaston Systems. 2012. Chemical Foam System. Available at: http://www.gastonsystems.com/

Guglani, R. 2008. Recent developments in Textile Dyeing Techniques. Available at: http://www.fibre2fashion.com/industry-article/pdffiles/12/1171.pdf

Han, S. O., H. Y. Choi. 2010. Morphology and surface properties of natural fibre treated with electron beam. Microsc Sci, Technol, Appl Educat, 3, 1880-1887.

Hasanbeigi, A., 2010. Energy-Efficiency Improvement Opportunities for the Textile Industry. Berkeley CA: Lawrence Berkeley National Laboratory Report LBNL-3970E . Available at http://china.lbl.gov/publications/energy-efficiency-improvement-opportunities-textile-industry

Hasanbeigi, A. 2013. Emerging Technologies for an Energy-Efficient, Water-Efficient, and LowPollution Textile Industry. Berkeley, CA: Lawrence Berkeley National Laboratory. LBNL-6510E.

Hauser, P. 2006. Advances and trends in textile wet processing chemicals. Journal of Textile and Apparel, Technology and Management, 5(1). Available at: http://www.tx.ncsu.edu/jtatm/volume5issue1/Hauser_trends.htm

Heine, E., H. Höcker. 1995. Enzyme treatments for wool and cotton. Review of Progress in Coloration and Related Topics, 25(1), 57-70. 
Hutten, I. M. 2007. Handbook of nonwoven filter media. Elsevier.

INTEXUSA. 2010. INTEXUSA. Available at: http://www.intexusa.eu/

Ishtiaque, S.M., K. R. Salhotra, R. V.M. Gowda. 2003. Friction spinning. Textile Progress, 33:2, 1-68

Kan, C. W., C. W. M. Yuen. 2007. Plasma technology in wool. Textile Progress, 39(3), 121-187.

Katović, D. 2011. Microwaves in Textile Finishing Yes or No. izlazi u samo elektroničkom izdanju: NE. Available at: http://bib.irb.hr/prikazi-rad?lang=en\&rad=576552

Katovic, D. 2010. Microwaves Solution for Improving Woven Fabric. Available at: http://cdn.intechweb.org/pdfs/12252.pdf

Katovic, D., S. B. Vukusic, S. Hrabar, J. Bartolic. 2005. Microwaves in chemical finishing of textiles. In Applied Electromagnetics and Communications, 2005. ICECom 2005. 18th International Conference. (pp. 1-4). IEEE. Available at: http://ieeexplore.ieee.org/xpls/abs_all.jsp?arnumber=1613471\&tag=1

Kulandainathan, M. A., K. Patil, A. Muthukumaran, R. B. Chavan. 2007a. Review of the process development aspects of electrochemical dyeing: its impact and commercial applications. Coloration technology, 123(3), 143-151.

Kulandainathan, M. A., A. Muthukumaran, K. Patil, R. B. Chavan. 2007b. Potentiostatic studies on indirect electrochemical reduction of vat dyes. Dyes and pigments, 73(1), 47-54.

Lewis, D. M. 1999. Coloration in the next century. Review of Progress in Coloration and Related Topics, 29(1), 23-28.

Massachusetts Executive Office of Environmental Affair (MEOEA). 1999. Toxics Use Reduction Case Study. Case Study No. 51, April 1999.

Matsuo, T. 2008. Innovations in textile machine and instrument. Indian Journal of Fibre \& Textile Research. Vol. 33, September 2008, pp. 288-303.

NANOVAL GmbH \& Co. KG. 2012. The Process: Filaments + Nonwovens. Available at: http://www.nanoval.de/verfahren_eng_fasern.htm

Nasadil, P., P. BENEŠOVSKÝ. 2008. Plasma in textile treatment. Chem. Listy, 102, s1486-s1489.

National Bureau of Statistics (NBS), 2011. China Energy Statistical Yearbook 2011. China Statistics Press. Beijing, China.

Nieminen, E., M. Linke, M. Tobler, B. V. Beke. 2007. EU COST Action 628: life cycle assessment (LCA) of textile products, eco-efficiency and definition of best available technology (BAT) of textile processing. Journal of Cleaner Production, 15(13), 1259-1270.

Nonwovens Industry. 2006. The Nanoval process--best for finefiber spunbonds. The Free Library. (2006, February 1). Retrieved July 18, 2013.

Oak Ridge National Laboratory (ORNL). 2012. U.S. Manufacturing Energy Use and Greenhouse Gas Emissions Analysis. Available at http://info.ornl.gov/sites/publications/files/Pub39685.pdf

Oxenham, W. 2003. Developments In Spinning. An overview of yarn formation technologies. Textile World. May 2003.

Oxenham, W. 2002. Current and future trends in yarn production. Journal of Textile and Apparel, Technology and Management. Volume 2, Issue 2, 2002.

Ozone Bleach Association. 2013a. How to Produce Ozone. Available at: http://www.ozonebleach.com/en/ozone-bleach/how_to_produce_ozone.htm

Ozone Bleach Association. 2013b. How Positive is Ozone Bleach for the Environment. Available at: http://www.ozone-bleach.com/en/ozone-bleach/how_positive_is.htm

Perincek, S. D., K. Duran, A. E. Korlu, İ. M. Bahtiyari. 2007. An investigation in the use of ozone gas 
in the bleaching of cotton fabrics. Ozone: Science and Engineering, 29(5), 325-333.

Prabaharan, M., R. C. Nayar, N. S. Kumar, J. V. Rao. 2000. A study on the advanced oxidation of a cotton fabric by ozone. Coloration Technology, 116(3), 83-86.

Ramachandran T., T. Karthik, D.Saravanan. 2008. Novel Trends in Textile Wet Processing. Journal of Institution of Engineers, volume 89, Aug 2008: 3.

Rane, V., A. Jadhav. Not dated (n. d.). Novel trends in Continuous Pretreatments. Available at: http://textile.netai.net/weaving\%202/442.pdf

Roessler, A., D. Crettenand. 2004. Direct electrochemical reduction of vat dyes in a fixed bed of graphite granules. Dyes and pigments, 63(1), 29-37.

Roessler, A., D. Crettenand, O. Dossenbach, W. Marte, P. Rys. 2002. Direct electrochemical reduction of indigo. Electrochimica Acta, 47(12), 1989-1995.

Rupp, J. 2012. Spinning With An Air Jet. Textile World. March/April 2012.

Sathaye, J., L. Price, L., S. de la Rue du Can, D. Fridley. 2005. Assessment of Energy Use and Energy Savings Potential in Selected Industrial Sectors in India. Berkeley CA: Lawrence Berkeley National Laboratory Report LBNL-57293. Available at: http://industrial-energy.lbl.gov/node/130

Schönberger, H.; Schäfer, T., 2003. Best Available Techniques in Textile Industry. Available at: http://www.umweltdaten.de/publikationen/fpdf-1/2274.pdf

Seyam, A. M. 2000. Advances in Weaving and Weaving Preparation. Textile Progress, 30(1-2), 22-40.

Shamey, R., T. Hussain. 2003. Artificial intelligence in the colour and textile industry. Review of Progress in Coloration and Related Topics, 33(1), 33-45.

Shim, W. S. 2009. A diagnostic expert system for the coloration of polyester materials. Available at: http://repository.lib.ncsu.edu/ir/handle/1840.16/3662

Sulzer Textile. 2002. Weaver's Digest. No. 3. September 2002.

Sulzer Textile. 2000. Economizing Resources by Cost-efficient Weaving. Sulzer Technical Review 1/2000: 7-9. Available at: http://www.sulzer.com/en//media/Documents/Cross_Division/STR/2000/2000_01_7_legler_e.pdf

Textile machinery. 2010. DyeCoo: waterless dyeing. Issue 3, 2010.

Textile World. 2012a. Saving Water a Swimming Poolful At a Time. Available at: http://www.textileworld.com/Articles/2012/December/November_December_issue/Saving_Water.html Textile World. 2012b. ColorZen Offers Water-, Energy-, Chemical- And Time-Saving Cotton Dyeing Technology. Available at: http://www.textileworldasia.com/Articles/2012/August/ColorZen_Offers_Water-_Energy-_Chemical_And_Time-Saving_Cotton_Dyeing_Technology.html

Textile World. 2002. DyStar Getzner Partner for Electrochemical Dyeing Trials. Available at: http://www.textileworld.com/Articles/2002/February/Dyeing_Printing_Finishing/DyStar_Getzner_Par tner_For_Electrochemical_Dyeing_Trials.html

Tušek, L., V. Golob, Ž. Knez. 2000. The effect of pressure and temperature on supercritical $\mathrm{CO}_{2}$ dyeing of PET-dyeing with mixtures of dyes. International Journal of Polymeric Materials, 47(4), 657-665.

Tyler, D. J. 2005. Textile digital printing technologies. Textile Progress, 37(4), 1-65.

United Nations, Department of Economic and Social Affairs (UN/DESA), 2012. World Population Prospects: The 2012 Revision. Available at http://esa.un.org/unpd/wpp/unpp/panel_population.htm

U.S. Department of Energy (U.S. DOE), Advanced Manufacturing Office (AMO). 2012. "Industries and Technologies." Available at http://www1.eere.energy.gov/industry/industries_technologies/index.html 
U.S. Department of Energy (U.S. DOE). 2013, Manufacturing Energy Consumption Survey (MECS)2010. Available at: http://www.eia.gov/consumption/manufacturing/data/2010/

U.S. Department of Energy (U.S. DOE). 2010, Manufacturing Energy Consumption Survey (MECS)2006. Available at: http://www.eia.doe.gov/emeu/mecs/mecs2006/2006tables.html

U.S. Environmental Protection Agency (U.S. EPA). 1996. Manual: Best Management Practices for Pollution Prevention in the Textile Industry (chapter 3). Available at http://infohouse.p2ric.org/ref/02/01099/0109904.pdf

Vouters, M., P. Rumeau, P. Tierce, S. Costes. 2004. Ultrasounds: an industrial solution to optimise costs, environmental requests and quality for textile finishing. Ultrasonics Sonochemistry, 11(1)33-38. 